\title{
The Collaboration of Higher Education Schools and SME's Institutional Structure Development
}

\author{
Prof. Ass. Dr. Alba Robert Dumi ${ }^{1}$ \\ Ma. Zamira Sinaj2 \\ Ma. Borana Kociu \\ a Prof As Dr, Dean of Graduated School"Ismail Qemali" Vlora University Albania, \\ Management Department \\ 1,2, 3Management Department, Economy Faculty, American Tirana University \\ Email:besi.alba@yahoo.com,sinajzamira@yahoo.com
}

\section{Doi:10.5901/jesr.2014.v4n1p11}

\section{Abstract}

This paper research overview of the leader behavior literature highlighted the fact that there are inconsistent relationships between the behaviors that leaders engage in and the effects of these behaviors on member attitudes, behavior, and group effectiveness in Albania and Vlore region In addition, for each study the national/regional and institutional strategy was reviewed and university of Vlore and wider literature consulted to highlight references to university business interactions in either education or research. The paper research study structure covers: 1. The national/ regional framework; 2. The institutional framework; 3. Rationale behind the collaboration 4.The objectives/benefits of collaboration. 5. The activities and the progress in learning and teaching. The behaviors are important as witnessed by their occasionally significant relationship with follower attitudes and behavior. Second, the observation that these behaviors do not always produce significant and positive effects suggests that something else is transpiring such that in one situation the particular leader behavior produces significant effects and in another situation that behavior is relatively unimportant. The question that these observations raise is. The objective of the study is to undertake a selection of institutional in-depth case studies which reflect different approaches to university business cooperation across a selection. The study took a mixed method approach to the construction of the case studies. We are trying to analyze on Albanian conditions and especially in Vlore region, the effects of using different hypotheses in some definitions of leadership theories, the implementation of effects of leader behavior in organizations. In this paper research, we contend, weakens important institutional qualities, resulting in institutional degradation. Once institutional actors identify problems and weaknesses with existing institutions, previously institutionalized logics are disrupted and the search for new logics, forms, and practices begins.

Keywords: Influence of university reforms, Institutional specialization, Human forces, Job market.

\begin{abstract}
"Higher education reform in Albania is equally urgent. Most European universities do not attract enough top global talent, with relatively few in leading positions in existing international rankings. European universities should be freed from over-regulation and micro-management in return for full institutional accountability. Universities also need more diversity in their missions and outlook, with smarter specialization across different fields" Source: EU Strategy 2013
\end{abstract}

\section{Introduction}

This is a difficult analyze in Albania and especially in Vlore region, in a region that has a significant number of small businesses many of which are traditional and so do not seek university aid. I and my colleague spend more on communication than any other university in Albania. As a result, AAU participates in a great number of private and public, local, national and international collaborations, networks, associations, partnerships, etc. at different levels within various areas of education and research. In 2009 alone, the university entered into almost 50 cooperative agreements with external partners. A study performed by The Confederation of Industry in 2008 reveals Albania University to be the developed corporate world's preferred business partner in research and development projects. Source: UEF report 2012 


\subsection{Hypotheses and rationale influences theory}

Europe has a heterogeneous landscape of higher education, not least in respect of university business collaboration. While the last 10 years following the Bologna initiative have seen significant changes in cooperation between universities and business, the theme is still addressed unevenly across Member States, regions and indeed individually at the level of the institution. In many of the new Member States, France, EU Countries etc university business cooperation is a recent and inchoate phenomenon, while some of them share with several of the old Member States a degree of skepticism attached to engaging with business and the extent to which academia has the task of ensuring graduate employability. The debate continues, but there is nonetheless a growing acceptance, encouraged by the European Commission, that higher education institutions and businesses do benefit from working together; collaboration stimulates the transfer and sharing of knowledge, and helps create long-term partnerships and profitable opportunities, as well as boosting student s' future employment prospects. (Source: Employer and University Engagement in the Use and Development of Graduate Level Skills. IFF Research 2007)

\subsubsection{The university - facts and figures in regional development}

Albania and Vlore region has historically adopted a regional development approach to growth: for the university, there is little help from the national government for third stream activities. Lectors and Professors have played a significant role in Albanian and Vlore regional development by becoming embedded in the region as a driver of change. This entails collaboration with regional and educational institutions as well as the creation of consortia and collaboration networks with national and international universities. It is AAU's aim to become the central institution for constructive collaboration with local institutions and business partners to enhance competence and business development.

\subsection{Development experiences and PBL project, one experience indicator for Albania}

Project and Problem Based Learning (PBL) or the 'Aalborg model', although a teaching and learning method, is the largest source of business interaction at AAU. Projects as a working method constitute approximately 50 per cent of the total study that a student engages in and last half a year. The model begins with the formulation of a problem. (Shuddeler PBL 2013)

Students define and analyze the problem within an articulated interdisciplinary or subject frame. Working in facultysupervised groups, the students plan, manage and complete a project that addresses the stated problem. Inspirational appeals use the target's values, ideals, aspirations, and emotions as a basis for gaining commitment to a request or proposal (Dumi A 2013, AJS). Inspirational appeals appear feasible for influence attempts made in any direction, but this tactic is especially appropriate for gaining the commitment of someone to work on a new task or project. Influence attempts and involving task assignments occur most often in a downward direction and least often in an upward direction (Erez1986, Kipnis1980, Yukl \& Falbe, MCSER 2013, vol 4, Dumi A, p 34.

A common primary reaction by actors within an organizational development factors (managers, board of directors, policy makers, political action groups, etc.) to environmental jolts is to instigate search processes in which they scrutinize the symptoms of the crisis and look for its causes (Cyert and March, 1963, p. 121).4

Thus managers have more opportunity to use inspirational appeals with subordinates than with peers or superiors. In the only prior study to examine directional differences for inspirational appeals, (Yukl and Falbe JERM(1990) found that inspirational appeals were used more in downward influence attempts than in lateral or upward influence attempts.

\section{Literature Review and Hypotheses}

Over the past two decades, "finding jobs for people" in response to high unemployment has been a top priority. Looking ahead, a new labor market priority for Newfoundland and Labrador will be "finding people for jobs". Looking ahead, opportunities will continue to grow as a result of planned major project developments, including the Hebron and Lower Churchill projects, expansion of the mining sector, and continued growth of the service economy. In order to take full advantage of these opportunities, sustain economic growth, and improve employment outcomes, the Provincial Government will continue the work it is doing to develop, attract, and retain a skilled workforce.

Source: Department of Human Resources, Labor and Employment 2020 year.

This is a compelling and difficult topic given that institutions are by dentition highly resistant to change. Neo- 
Institutionalisms describe institutions as reutilized structures and behaviors that are taken for granted as "the way things are done," and therefore, escape day-to-day scrutiny (Berger and Luckemann, 1966; Meyer and Rowan, 1977; DiMaggio and Powell, 1991; Scott, 1995). Institutions are described as decoupled from typical measurable performance outcomes, and their worth is linked more to their historicity and symbolic value than to the relative effectiveness of their technical contributions, which are often assumed by constituents (Berger and Luckmann, 1966; Meyer and Rowan, 1977). Yet, even in highly institutionalized held, change can occur. In this paper, we seek to elucidate the relationship between institutional change and opportunities for entrepreneurship (Research Policy 32 (2003) 185-207, Sine and Davide

With respect to the types of businesses involved in collaboration with universities, the case studies show a similar range as in the geography above, though some institutions, such as Charles University in Prague and the National Technical University of Athens work for the greater part with public, rather than private, bodies. There is growing interest among organizational scholars in the relationship between institutional change and entrepreneurial action (DiMaggio, 1988, 1991; Greenwood and Hinings, 1996; Barley and Tolbert, 1997; Fligstein, 1997; Hoffman, 1999).

For the others, at the high end of knowledge and technology transfer, there is an international dimension, usually through the presence of global corporate in the vicinity, sometimes in a science/business/research park, as in the examples of Leuven, Limerick, Madrid and Surrey. Enterprise development, perhaps by way of spin out or spin off, tends to produce new SMEs, while curriculum development activity and sponsored chairs usually engages the larger companies and institutions. (University Collaboration in Regional Development Spaces - http://www.unicreds.eu )

Project spoke of the relative ease with which universities can engage with larger enterprises, suggesting that the real challenge still remained the effective engagement of SMEs: "The links between universities and large businesses are important but can be relatively straightforward. However, building up partnerships with SMEs is more challenging. SMEs are an important part of the economy in peripheral regions such as those involved in UNICREDS, and it is vital that strong, innovative policy structures are in place to support them." At the same time, there needed to be recognition of the difficulties, such as higher transaction costs, and achievement of critical mass, involved in engaging SMEs in relationships with HEls. (University Collaboration in Regional Development Spaces - http://www. unicreds.eu)

Agents reported greater use of this tactic in upward influence attempts, but directional differences were not found for targets. Results for the consequences of using rational persuasion have been inconsistent also. In the questionnaire study by Kipnis and Sshmidt (1988) managers who received the highest performance ratings had a profile in which rational persuasion was the dominant tactic for upward influence attempts. However rational persuasion was not related to successful upward influence in the questionnaire study by Mowday (1978). Likewise tactics involving aspects of rational persuasion were not related to outcome success in the four critical incident studies described. Dumi A 2013, AJS

Tab 1.The cycle of rationality developments of hypotheses, Source: Medway theory concepts 1978

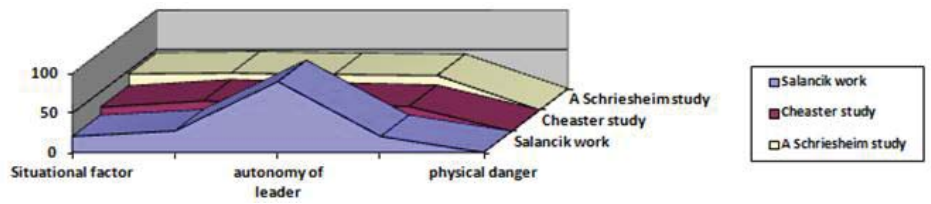

Hypothesis1a. Rational persuasion is used more in an upward direction than in a downward or lateral direction. (The analyzing data from NL labor force)

Over the last decade (2000 and 2010) employment grew by $10.4 \%$ in Newfoundland and Labrador and the provincial labor force grew by $7.6 \%$.

Women have been a major force in the labor market, with employment and labor force growth significantly outpacing that of men. Women have accounted for $71.7 \%$ of all labor force growth and $78.2 \%$ of all employment in the last 10 years. These trends are not surprising considering women were not traditionally part of the paid workforce and have been entering the workforce at a dramatic pace over the past 35 years.

The number of women in the workforce has more than doubled since 1976 , growing by $110.8 \%$ compared to $6.6 \%$ growth among men in the workforce.

The rate of labor force growth has slowed for both women and men over the past five years. Between 2005 and 2010 , the number of women in the labor force grew by $3.9 \%$ compared to $7.5 \%$ over the 2000 to 2005 period. Similarly, labor force growth rates among men dropped to $0.5 \%$ in the 2005 to 2010 period compared to a growth rate of $3.4 \%$ in 
the proceeding five years.

Hypothesis1b. Rational persuasion increases task commitment in all three directions.

When people gain a sense of ownership of a project, strategy, or change after participating in planning how to implement it, they are likely to be more committed to making the project, strategy or change successful (Yukl 1989). This influence tactic can be used in any direction, but it appears especially appropriate in the situation in which an agent has the authority to plan a task or project but relies on the target to help implement the plans. Because authority to assign work and make changes in work procedures is mostly downward a manager probably has more opportunity to use consultation to influence subordinates than to influence peers or superiors (Yukl \& Falbe, 1990.

\subsection{The variety of hypotheses and limited results.}

In the tradition of Leblebici et al. (1991), we use historical analysis to examine the relationship between environmental jolts, held level search processes, and institutional change in the electric power industry. This requires that we provide at first the evidence that the industrial form of a regulated monopoly was indeed institutionalized within the electric power organizational held. Second we must establish the effect of jolts on held level search processes, particularly the mobilization of institutional actors, such as policy makers, innovators/entrepreneurs, academics, and popular social movements (such as environmental groups and consumer activists) (W.D. Sine, R.J. David / Research Policy 32 (2003) 185-207)
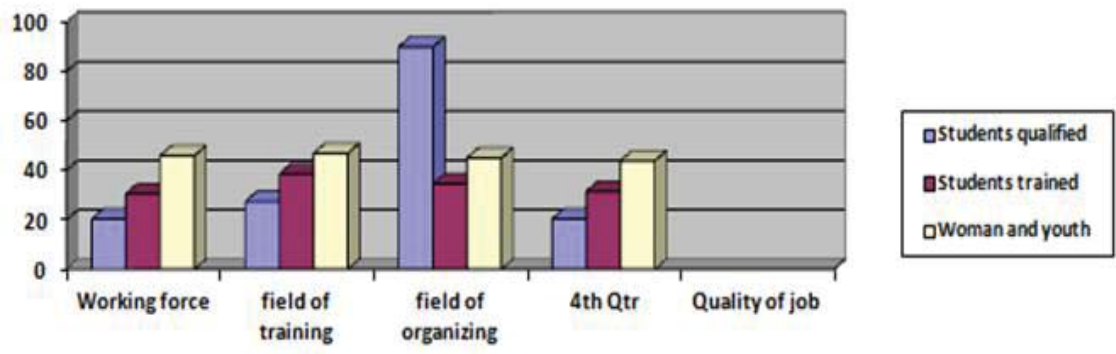

Source: W.D. Sine, R.J. David / Research Policy 32 (2003) 185-207)

The students do not necessarily work on the premises of a partner company to solve a problem, as a project may need as few as one or two meetings with the company. When companies do hire students, they get highly qualified workers capable of performing a variety of jobs. As the university is directly involved in the hiring process and terms of the employment, the company and the student determine the duration of the collaboration. Thus, the student can work in the company for an extended period of time, which means the company can involve the student in the day-to-day work to a larger degree than what is possible in connection with student projects or traineeships, and at the same time the student gets extensive insight into the company's work processes, products and projects. In this way, the student gets a taste of what the company is like in terms of employment. Only one study examined directional differences in frequency of use for consultation (Yukl \& Fable, 1990) and results were mixed. (Dumi A 2013, AJS) A variety of environmental factors contributed to the institutionalization of the electric power industry's structure, such as its designation as a "natural monopoly," low fuel prices, and rapidly advancing technology. This resulted in low electric rates, and political and popular satisfaction with the industry.

Any real impetus to scrutinize the appropriateness of the power industry's structure of regulated regional monopolies was ultimately lacking. As Cyert et al. (1965) explained, search processes are motivated by either dissatisfaction or conspicuous alternatives. The static environment between 1940 and 1965 provided neither. In this section, we review the factors that contributed to this stability (W.D. Sine, R.J. David / Research Policy 32 (2003) 185207)

Agents reported greater use of consultation in a downward direction, but directional differences were not significant for target reports. Evidence on the likely effectiveness of consultation as an influence tactic is limited and inconsistent. Locke (1982) found that a consultation tactic (using the target as a platform to present ideas) was likely to be effective in upward incidents reported by targets, but the results were not significant for upward incidents reported by 
agents in that study Locke (1988).

\subsubsection{The significant indicators of this paper research study.}

In the study by Vroom (1988) of downward incidents reported by agents, results for consultation tactics (listening, soliciting ideas) were not significant. Indirect evidence comes from research on leadership, which finds that consultation with individual subordinates is effective for increasing decision acceptance in some situations but not in others (Vroom \& Jetton, 1988) Hypothesis2a. Inspirational appeals are used more in a downward direction than in a lateral or upward direction. Hypothesis2b. Inspirational appeals increase task commitment in all three directions. Since 2000, the participation rate among women (15 to 64 years old) rose by 8.7 percentage points to stand at $67.6 \%$ in 2010 . In this same period, the participation rate for men rose by 5.6 percentage points to stand at $74.4 \%$ in 2010 .

The importance of the situation has already been alluded to on numerous occasions through the first several theories. Murphy 91941), for example noted that situations in which people find themselves create needs, and it is the nature of these needs that defines the type of leadership that best serves the group. Participation rates also vary across regions of the province.

This is largely due to differences in industry and age structure. The St. John's Census Metropolitan Agglomeration (CMA) tends to have a much stronger dependency on service sector industries whereas areas outside the CMA have a stronger dependency on primary industries which tend to be highly seasonal.

Workers in more rural areas of the province also tend to be older than the provincial average. Source: www.aes.gov.nl.cap

Accordingly, Murphy theory and findings, saw leadership is a working relationship-one in which different contexts create one unique set of group needs, and a group's emerging leader is that individual who is capable of making meaningful contributions to the group. We are focus in "Hypothesis $3 a$ and $3 b$ to overview in indicate of their effects.

The seasonal variations also pose implications for monitoring labor market conditions throughout the year. In this province, it is more relevant to compare monthly results to the same month in previous years to observe the changes that are occurring. These hypotheses, helps us created the leaders modeling according Webber theory. Hypothesis3a. Consultation is used more in a downward direction that in a lateral or upward direction.

Hypothesis3b. Consultation increases task commitment in all three directions. Three keys questions that will be addressed are:

- Does the situation in which the leader and follower are embedded make a difference?

- What leader behavior works and when?

- What is the process through which the situation produces its effects

\subsection{Strategic leadership models and critical leadership situations. (NL and WAS activities and data)}

In March of 2009 and 2010, the Department of Human Resources, Labor and Employment (HRLE) conducted a provincial Work Activity Survey (WAS) to gain a better understanding of the dynamics and characteristics of the provincial workforce, especially with respect to unemployed workers and the impacts of seasonal employment. Changes in the number of hours people work during the week is another key indicator of labor market conditions. In 2010, 85.3\% of workers in Newfoundland and Labrador were employed in full-time jobs compared to $80.7 \%$ for Canada overall. Canadian case study: www.aes.gov.nl

In Salancik and Pfeffer's (1977) strategic contingencies model of leadership, the leader is a person who brings scarce resources to assist a group of individuals in overcoming a critical problem that they face. As the problems facing a group change, their leader may also change because of his or her access to critical and scarce resources. Thus, Salancik and Pfeffer's work also serves to highlight the importance of the situation in defining leadership and the leadership process. Tab 2 shows the influences of situational leadership theory (University Collaboration in Regional Development Spaces - http://www.unicreds.eu)

UAM is a multi-disciplinary HE institution with a strong focus on both education and research.

Its academic structure broadly reflects the typical 'tracks' of the Spanish HE system, notably the academic track, whereby students follow a four- to six-year program in liberal education and professional programmers offered in faculties (e.g., Law, Business and Economics and Medicine); and, the University Schools, offering three-year programmers in teaching or nursing, for instance. 
Tab. 3: Influences of situational propositions of leadership context with different authors theories.

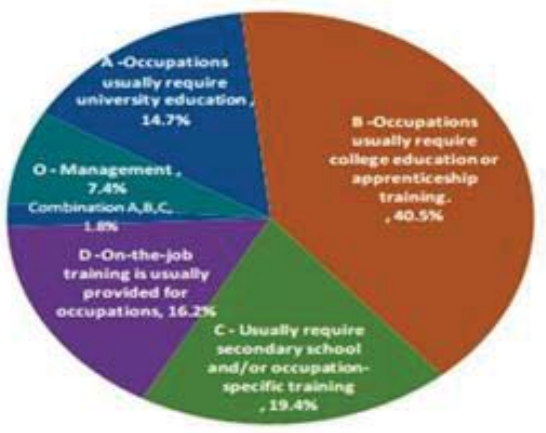

Source: Leadership process, year 2008, USA, FIG: Distribution of Employment by Skill Level, NL, 2005

Influenced by Stogidill's $(1948,1974)$ reviews of the leader behaviors literature and the emerging recognition of the importance of the leadership context, Steven Kerr, Charles Murphy and Ralph Stogidill (1974), advanced a number of situational propositions linking leader of structure and consideration to a leader effectiveness. They note that accumulated evidence suggests that leader effectiveness is not always associated with those who behave in highly considerate and structuring manner. Among some of the situational factors that influence the effectiveness of leader consideration and initiating structure behavior are, for example, time urgency, amount of physical danger presence of external stress, degree of autonomy, degree of job, scope, importance, and meaningfulness of work. Like the rest of Canada and most developed economies, the services sector represented the largest share of employment (79.6\%) in Newfoundland and Labrador in 2010.

The services sector has been steadily gaining a larger share of employment since the mid-1970's and is strengthening its hold as the mainstay of the economy, having accounted for $88.8 \%$ of all employment growth in the province between 2000 and 2010. Canadian case study: www.aes.gov.nl

\section{Methodology and Research Goal}

Findings - The research resulted in mixed findings that only partially support the mediating effect of organizational politics on the relationship between leadership, in-role performance and OCB. A direct relationship between leadership and performance (in-role and $\mathrm{OCB}$ ) was also found. the largest industries in the province in 2010 included health care and social assistance (16.7\%); retail trade (14.5\%); educational services (7.8\%); public administration (8.5\%); and construction (7.0\%).

Fig: Distribution of Employment by Skill Level, NL, 2005

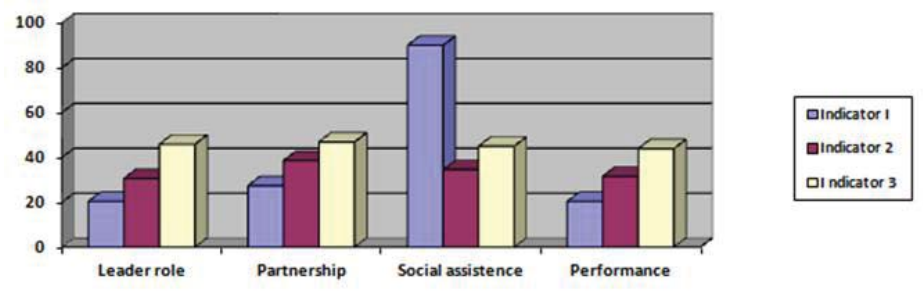

This study empirically examines the impact of debt management policies on borrowing costs incurred by state governments when issuing debt in the municipal bond market. Based on positive political theory and the benefit principle of taxation, it is proposed that states that adhere to best practice debt management policies transmit signals to the credit ratings, investment community and taxpayers that the government should meet its obligations in a timely manner, 
resulting in lower debt costs. ${ }^{1}$ The donors concurred with this assessment. IDA, starting with the 1998 CAS, considered governance and institution building as one of the central planks of its intervention and identified the need to adopt and implement reforms to build an accountable and transparent state as the most important challenge facing the Government of Albania.

Hypothesis4a. Ingratiation is used more in a downward and lateral direction than in an upward direction.

Hypothesis $4 b$. Ingratiation has a stronger positive effect on task commitment in a downward and lateral direction that in an upward direction.

Robert House (1971) contends that leader effectiveness is most appropriately examined in terms of the leader's impact upon the performance of his or her followers. In the first reading in this chapter, House and Terence Mitchell (1974) assert that a leader's behavior will be motivational and subsequently have an impact upon the attitudes and performance behavior of the follower to the extent that it makes the satisfaction of a subordinate's needs contingent upon his or her performance.

Tab. 4: Long term characterized and short term perspectives. Source: Dumi A, MJSS, Nr 32012

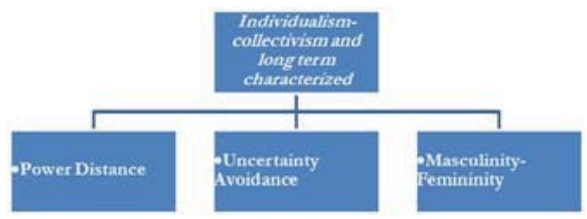

Long-term orientation is characterized by a long-range perspective coupled with a concern for thrift and weak expectations for quick returns on investments (Pacific Rim countries).

Short-term orientation is characterized by a long-range perspective coupled with a concern for thrift and weak expectations for quick returns on investments (Pacific Rim countries).

\section{The Strategic Planning of E-Learning in the Albania}

E-Learning is gaining significant interest in distance education, including university and other. It also get a special importance in terms of exchanges of experiences between different institutions within and outside the country. Despite the distance people already have the opportunity to learn from others, or used in any other time and place that they are. These advantages are powered by technological developments, developments that require a generation as qualified to be adopted in time with the rapid technologic evolutions. The advantages of using e-learning are related to the degree of qualification of the generation which lives in an era of rapid technological change. Despite the rapid technological development in many countries there are benefits from the use of e-learning or there are benefits that are not at levels as it's required.

\section{Conclusions and Recommendations}

The effects of contingent punishment are unique in that this behavior has a desirable effect in only one of the Western countries (the United States) and in neither of the two Asian countries studied. Leaders who demonstrate supportive kindness and concern for followers are valued and effective in each of the countries studied. Leaders' contingent behavior is highly effective in the more collectivism Asian cultures-as it often is in Western countries. The readings in this and the preceding chapter sensitize us to the contextual factors with which leaders need to contend. Specifically Hofstede (1993) and Dorfman (1997) alert us to the fact that not all followers will have the some belief and value orientation. These differences clearly have leader and leadership implications. Our earlier reading by Murphy (1941) suggested that leadership function of an interaction between the leader, the situation and the follower. In this paper we will focus on the follower in the leadership process. We will want to carry into those readings and understanding of the individual differences that are produced by cultures and differential belief/value systems.

${ }^{1}$ Donors and government investments, IDA 


\section{References}

Alb invest Albania

Albanian websites on European integration

"Basic orientations for the sustainability of European tourism"(2003). The commission of the European Communities, COM 716, Brussels.

Cardoso, C., and Ferreira, L. 2000. The effects of European economic integration on tourism: challenges and opportunities for Portuguese tourism development.

International Journal of Contemporary Hospitality Management. 12(7): 401-408 ETC. (2005). Brussels, Murphy, P.E. 1988.

Community-driven tourism planning. Tourism Management.9(2)

Dobbins, G.H \& Platz, S.J. sex differences in leadership: How real are they? Academy of Management Review, 1986, 11(1), 118-127.

Denison, D.R. Hooijberg, R \& Quinn, R.E.Paradox and performance: a theory of behavioral complexity in managerial leadership. Organization Science. 6(5), 524-540.

Falbe, C.M \& Yukl, G.Consequences for managers of using single influence tactics and combinations of tactics. Academy of Management Journal, 1992, 35(3), 638-652.

Fiedler, F.E. a theory of leadership effectiveness. New York: McGraw-Hill, 1967.

Gillespie, H.R. An investigation of current management/leadership styles of manufacturing executives in American industry. Dissertation Abstracts International, 19801, 41(7a), 3177.

Harris, T.G. the post-capitalist executive: an interview with Peter F.Drucker. Harvard business review, 1993, 71, 114-122.

Hart, S.L \& Quinn, R.E. Roles executives play: CEOs, behavioral complexity, and firm performance. Human Relations, 1993, 46(5), 543574.

Hersey, P \& Blanchart, K.H. Management of organizational behavior: utilizing human resource (4th, ed). Englewood Cliffs, NJ: PrenticeHall, 1982.

Hooijberg, R...,\& Quinn, R.E. Behavioral complexity and the development of effective managers. In R.L. Phillips and J.G.Hunt (eds), strategic management: A multi organizational -levels perspective. New York: Quorum, 1992.

House, R.J. A path-goal theory of leader effectiveness. Administrative Science Quarterly, 1971, 16, 321-338.

House, R.J \& Mitchell, T.R. Path -goal theory of leadership. Contemporary Business, 1974, 3(Fall), 81-98.

Howell, J.M \& Higgins, C.A. Champions of technology. Administrative Science Quarterly, 1990, 35, 317-341.

Joreskog, K.G \& Sorbom, D. Liserel 7: User's reference guide. Mooresville, IN: Scientific Software, 1989.

Kanter, R.M. the new managerial work. Harvard Business Review, 1989 (November-December).

Katz, D.A \& Zaccaro, S.J. An estimate of variance due to traits in leadership. Journal of Applied Psychology, 1983, 68(4), 678-685.

Kester, F \& Wollenberg, A.L. van den. Modulair system methodenleer Quasi experimenteel design. Vakgroep Mathematische Psychologie, Psychologisch Laboratorium, Nijmegen, 1986.

Kipnis, D \& Schmidt, S.Upward influence styles: Relationship with performance evolution, salary, and stress. Administrative Science Quarterly, 1988, 33, 528-402.

Kotter, J.P. the general managers. New York: Free Press, 1982.

Lieberman, S. the effects of changes in roles on the attitudes of role occupants. Human Relations, 1956, 9, 385-402.

Luthans, F \& Lockwood, D.L. Toward an observation system for measuring leader behavior in natural settings. In J.G. Hunt, D. Hosking, C.A> Schriesheim, and R.Steward (eds), Leaders and managers: international perspectives on managerial behavior and leadership. New York : Pergamon Press, 1984.

Mintzberg, H. The nature of managerial work. New York: Harper and row, 1973

Morse, J.J \& Wagner, F.R. Measuring the process of managerial effectiveness. Academy of Management Journal, 1978, 21, 23-35.

Park, R.E. behind our masks. Survey, 1926, 56, 135-139.

Pinder, C, Pinto, P.R \& England, G.w. Behavioral Style and Personal Characteristics of Managers. Technical report, University of Minnesota, Center for the study of organizational performance and human effectiveness, Mineapolis, 1973.

Quinn, R.E. Beyond rational management. Mastering the paradoxes and competing demands of high performance. San Francisco: Jossey-Bass, 1988.

Quinn, R.E. Spreitzer, G.M \& Hart, S.Challenging the assumptions of bipolarity: interpenetration and managerial effectiveness. In S.Srivastva and R. Fry (eds). Executive continuity. San Francisco, CA: Jossey-Bass, 1991.

Schlenker, B.R. Impression management: the self-concept, social identity and interpersonal relations.Monterey,CA: Brooks/Cole Publishing Company, 1980.

Staw, B.M \& Ross, J. Journal of Applied Psychology, 1980, 65(3), 249-260. 